\title{
Gidalarda Bulunan Mikrobiyal Patojenlerin Karakterizasyonunda Real Time PCR Teknolojisi
}

\author{
Esen TUTAR $^{1}$, Elif KÖKSALAN ${ }^{2}$, İsmail AKYOL ${ }^{3 *}$ \\ ${ }^{1}$ KSÜ, Fen Bilimleri Enstitüsü, Biyomühendislik ve Bilimleri ABD, Kahramanmaraş \\ ${ }^{2}$ KSÜ, Ziraat Fakültesi, Zootekni Bölümü, Kahramanmaraş \\ ${ }^{3}$ KSÜ, Ziraat Fakültesi, Tarımsal Biyoteknoloji Bölümü, Kahramanmaraş
}

Geliş (Received): 30.06.2015

Kabul (Accepted): 20.09.2015

\begin{abstract}
ÖZET: Gıda kaynaklı mikrobiyal patojenler tüm dünyada hastalık, ölüm ve ciddi ekonomik kayıplara neden olan önemli bir sorundur. Olumsuz etkilere yol açan gıda kaynaklı hastalıkların önüne geçilebilmesive potansiyellerininbelirlenebilmesiiçin hastalığa neden olan mikrobiyal etkenin ve miktarının tanımlanması ve belirlenmesi gerekmektedir. Gida kaynaklı hastalıklara neden olan gida patojen mikroorganizmaların spesifik ve tekrarlanabilir bir metot ile tanımlanmaları önem arz etmektedir. Enfeksiyon dozu yaklaşı 10 bakteri hücresine kadar düşebilen mikrobiyal gıda patojenlerinintespitihassas, türe spesifik ve güvenilir bir metot gerektirmektedir. Kültürel, immünolojik ve konvansiyonel PCR metotlarıpatojenlerin tanısında yaygın olarak kullanılmaktaancak uzun zaman alması ve miktar ile ilgili yeterli bilgi vermemesi gibi sınırlamaları bulunmaktadır. Real Time PCR teknolojisi hassasiyeti, düşük miktardaki mikroorganizmaları belirleyebilme limiti, spesifikliği ve hızı gibi özelliklerinden dolayı mikrobiyal tanımlamada güncel ve güvenilir bir yöntemdir. Bu derleme çalışmasında, Real Time PCR tekniği yaklaşımları ve gıda patojenlerinde ve diğer mikrobiyal çalışmalara uygulanma potansiyelleri detaylandırılmıştır.
\end{abstract}

Anahtar Kelimeler: Gıda kaynaklı hastalıklar, Gıda patojenleri, Real time PCR

\section{Real time PCR Technology in Characterzitaion of Foodborne Microbial Pathogens}

\begin{abstract}
Foodborne microbial pathogens are major issue that gives rise to illness, death and serious economic losses all over the world. It is necessary that microbial factors and its amount cause to disease should be well defined to prevent foodborne diseases causing negative impact and determine its potential causes. Foodborne microbial pathogens that cause the foodborne diseases must be identified by a specific and reproducible method. Identification method of foodborne microbial pathogens that have infection doses as low as about 10 bacterial cells should be sensitive, specific species and reliable. Although cultural, immunologic and conventional PCR methods widely used in identification of microbial pathogens, they have some limitations including insufficient quantitative information of the tested micro-organisms and longtime requirement. Real time PCR technology is an up-to-date and reliable method in microbial identification due to its accuracy, specificity, low detection limit and rapidity. In this review, real time PCR approaches and application potentials in foodborne microbial pathogens and other
\end{abstract} microbial researches are emphasized.

Key Words: Foodborne diseases, Foodborne microbial pathogens, Real Time PCR

\section{GíRIŞ}

Gıda kaynaklı mikrobiyal hastalıklar patojen mikroorganizmalar tarafından kontamine olmuş gıdaların tüketilmesi sonucu ortaya çıkan önemli bir halk sağlığı sorunudur. Hastalık, ölüm ve ciddi ekonomik kayıplara neden olan gıda kaynaklı patojenler gıdaların üretimden tüketime kadar uygulanan işlemlerin herhangi bir aşamasında gıdalara bulaşarak insanlarda hastalığa sebep olmaktadır. Kontamine olmuş gıdaların tüketilmesi sonucu, patojen veya toksinleri sindirim sisteminde bir bariyer görevi gören bağırsaklardaki epitel hücrelerinden geçerek, genellikle gıdanın tüketilmesinden 6-7 saat sonra ishal, bulant1, kusma gibi klinik belirtiler göstermektedir. Gida kaynaklı mikrobiyal hastalıklar genellikle bitki veya hayvan orjinli olup en çok bebekler, çocuklar, yaşlilar ve hastalar gibi bağışıklık sistemi zayıf bireylerde görülmekle beraber az gelişmiş ve gelişmekte olan ülkelerde daha sık rastlanmaktadır. Gıda kaynaklı hastalıkların son dönemlerde bir ivme kazandığıve buna neden olarak ise gida endüstrisinin globalleşmesi, insanların yaşam ve yeme alışkanlıklarının değişmesi, çevresel kirlilik, uluslararası seyahat, iklim değişiklikleri ve mikroorganizma popülasyonlarındaki değişimler gibi faktörlerin etken olduğu düşünülmektedir (Velusamy ve ark., 2012).

Hastalık etmeni olan mikroorganizmalargıdalara enfeksiyon, toksikasyon ve toksienfeksiyon olarak bilinen üç farklı yollabulaşmaktadır. $\mathrm{Bu}$ bulaşma yollarında hastalık ajanı ya patojen mikroorganizmanın kendisiya da ürettiği toksinlerdir (Bhunia, 2008; Aytac ve ark., 2014). Campylobacter, Salmonella, Listeriamonocytogenes ve Escherichiacoli O157:H7 gibi patojen bakteriler gıdalara bulaşarak gidanın tüketilmesi ile canlı vücuduna girmekte ve canlı vücudunda varlığı veya ürettiği metabolizma ürünleri ile enfeksiyon oluşturmaktadır. Bacilluscereus, Clostridiumbotulinum ve Staphylococcusaureus gibi 
bakteriler ise ürettikleri toksinleri içeren gıdaların canlı vücuduna alınması sonucu hastalığa neden olmaktadır (Velusamy ve ark., 2012). Toksienfeksiyonda ise gidalar aracılığı ile vücuda alınan Clostridium perfringens gibi canlı patojen mikroorganizmaların tüketilmesi ve daha sonra bu mikroorganizmaların vücutta sporlanma, kolonizasyon ve toksin üretmesi ile oluşmaktadır (Aytac ve ark., 2014). Patojen mikroorganizmaların hastalık oluşturabilmesi için gıdalara bulaşması ile birlikte belirli bir sayıda olması gerekmektedir. Enfeksiyon dozu olarak bilinen bu değer patojenden patojene farkl1lık gösterdiği gibi bireyden bireye de farklılık gösterebilmektedir. Salmonella gibi bazı patojenler yüksek enfeksiyon dozunda hastalık oluşturabilirken E. coli O157:H7 patojeni gibi bazı patojenler ise düşük bir enfeksiyon dozundabile hastalık oluşturabilmektedir (Bhunia, 2008).

Gıda kaynaklı mikrobiyal hastalıklarısınırlamada en önemli adım hastalık etkeni olan gida kaynaklı mikroorganizmaların tür olarak doğru tanımlanması ve mikrobiyal popülasyonlardaki, düşük miktarlarının bile doğru belirlenmesidir. Enfeksiyon dozu yaklaşık 10 bakteri hücresine kadar düşebilen bu mikroorganizmaların doğru, güncel ve tekrarlanabilir metotlar ile tanımlanmalıdır. Patojen mikroorganizmaları tanımlamada kullanılan metotları kültür ve koloni bazlı metotlar, immünolojik metotlar ve moleküler metotlar olarak listelemek mümkündür. Kültür ve koloni bazlı metotlarınuzun zaman alması, bakterilerin her zaman aynı fenotipik özellikleri göstermemesi, fenotipik özelliklere bakılarak tanımlamada ve sınıflandırmada ortaya çıkan zorluklar gibi sınırlamalarıbulunmaktadır (Malorny ve ark., 2003). İmmünolojik metotlar ise kontaminasyon riskinin fazla olması, düşük miktarlardaki patojenleri tespit edememesi ve antijen-antikor ilişkisinde ortaya çıkanzorluklar nedeniyle tanımlamada dezavantajları vardır (Velusamy ve ark., 2010; Jasson ve ark., 2010). Moleküler metotlar, bu metotlara alternatif olarak geliştirilmiş DNA esaslı metotlar olup diğer metotlara göre hızlı, güvenilir, hassas, özgül ve tekrarlanabilir metotlar olarak gida kaynaklı patojen mikroorganizmaların teşhisindekullanılmaktadır. $\mathrm{Bu}$ metotlar bakteriyel sinıflandırmada özellikle de fenotipik açıdan atipik bakteri suşlarının tanımlanmasında son derece güvenilirdir.

\section{MIKROBIYAL TEŞHISTE YAYGIN KULLANILAN MOLEKÜLER TEKNIKKLER}

Moleküler teknikler gıdalarda hastalık etkeni olan mikroorganizmaların taksonomik seviyede teşhis etmek ve mikrobiyal yüklerini belirlemek amacıyla yaygın olarak kullanılmaktadır. Nükleik asitlerin hibridasyonuna dayalı olan bu metotlar içinde en çok uygulanan teknik ise yüksek duyarlılı̆̆ yönlülüğü ile PCR tekniğidir. PCR temel olarak DNA üzerinde belirlenen hedef bölgenin o bölgeye özgü primerler ile çok sayıda kopyasının oluşturulduğu bir reaksiyondur. PCR sonrası ürünlerin varlığı elektroforez tekniği ve genellikle floresans bir boya olan etidyum bromür ile boyanmış DNA'nın görüntülenmesi sonucu tespit edilebilmektedir. Elektroforez tekniğinde kullanılan DNA belirteçleri ile de yarı kantitatif sonuç alınabilmektedir. Ayrıca bir sonraki adım olarak nükleotid dizileme teknolojinin uygulanmasına olanak sağlamaktadır. Böylelikle genom ile ilgili daha çok ve daha güvenilir bilgi elde edilebilmektedir.

Gida kaynaklı mikrobiyal hastalıklara neden olan patojenlerin PCR ile tanımlanmasında saf kültürler veya ön zenginleştirme ya da seçici besiyerinde geliştirilen gıda örnekleri kullanılmaktadır. PCR tekniğinde saf kültürler kullanıldığında kontaminasyon riski düşükken ön zenginleştirme besiyerinden alınan örneklerin analizinde kontaminasyon riski daha yüksek olmaktadır. Santrifüjleme, filtrasyon ve yıkama aşamaları gibi basit bir örnek hazırlama yöntemi kontaminasyonları elemine etmek için yararlı olabilmektedir. Bununla birlikte gıda örneklerinden saf bir DNA elde etmek için örneklerin seyreltilmesi ve daha sonra mikroorganizmanın uygun koşullarda büyütülmesi gibi önişlemler uygulanabilmektedir. Böylece sadece canlı hücreler kopyalanmakta, düşük sayıdaki mikroorganizmaların seviyesi artmakta ve gida matriksinden kaynaklı inhibitörler elemine edilebilmektedir (Hill ve ark.,1996). Örneklerde bulunan ölü ve canlı hücreler örnek hazırlama aşamasında etidyum monoazit ve propidyum monoazit gibi bileşikler kullanılarak da elemine edilebilmekte ve yanlış pozitif sonuçlar engellenebilmektedir (He ve ark., 2010). PCR kültürel bazlı metotların son aşaması veya doğrulanması olarak kabul edilebilir ve zaman olarak da daha kısa sürede sonuç elde edilebilmektedir. Gıda kaynaklı patojenlerin PCR bazlı metotlar ile tanımlanabilmesi için hedef gen bölgesinin seçimi önem taşımaktadır. Genellikle 16S rRNA geni mikroorganizmaların tanımlanmasında hedef gen bölgesi olarak kullanılmaktadır. Yüksek derecede korunmuş olması, bütün bakterilerde çok sayıda kopyasının bulunması ve farklı bakteriler arasında önemli ölçüde dizi çeşitliliği ile 9 hiper değişken bölge içermesi (V1-V9) gibi özellikleri hedef gen bölgesi olmasının nedenlerindendir (Beneduce ve ark., 2007). 16S rRNA gen bölgesi cins ve tür seviyesinde ayırım yapabilmek için hedef gen bölgesi olarak kullanılabilmekte ama değişken gen bölgelerinin yüksek derecede benzerlik göstermesi nedeniyle bazı bakterilerin suş ve serotiplerini ayırmak için yeterli olmamaktadır. Tür altı seviyede ayırım yapabilmek için kullanılan hedef gen bölgesi ise intergenik RNA boşluk bölgeleri olarak seçilmiştir. $\mathrm{Bu}$ protein kodlamayan bölgeler evrim sürecinde daha az baskıya maruz kaldıklarından dolayı değişkenlik göstermekte ve tür altı seviyede sınıflandırma yapabilme imkanı sunmaktadır (Rijpens ve ark., 2002).

PCR tekniğinin gelişmesi ile Ters Transkriptaz PCR (Reverse Transcriptase PCR; RT-PCR), PCR Ürününün Endonükleaz ileKesilmesi (PCR-RFLP), Çoğaltılan 
PCR Fragmentlerin Uzunluk Polimorfizmi (Amplified Fragment Length Polymorphism; AFLP) ve Çoklu PCR (Multipleks PCR) gibi farklı PCR temelliteknikler geliştirilmiştir. Tüm PCR bazlı teknikler PCR'ın modifiye edilmesi ile oluşturulmuş, PCR'ın dezavantajlarını ortadan kaldırmak, gida kaynaklı patojen mikroorganizmaların tanımlanmasında hassasiyeti ve özgüllüğü artırmak amacıyla oluşturulmuş metotlardır. Birçok araştırmacı bu teknikleri kullanarak gida kaynaklı mikrobiyal hastalıklara etken mikroorganizmaları tanımlamışlardır (Wiedmann ve ark., 1992; Lindqvist, 1999; Ripabelli ve ark., 2000; Yaron ve Matthews, 2002; Bottero ve ark., 2004; Pinto ve ark., 2005; Rodriguez-Palacios ve ark., 2006; Beneduce ve ark., 2007; Cawthorn ve ark., 2008). PCR teknolojisi gida kaynaklı mikrobiyal patojenleri tanımlamada önemli bir araç olmasına rağmen bazı sınırlamalara sahiptir. PCR' da kullanılan primerlerin kendi içlerinde ya da birbirleri arasında yanlış eşleşmeler oluşturması yanlış pozitif sonuçlara neden olabilmektedir. Ayrı PCR ürünleri görüntülemek için etidyum bromür ile boya işlemi hem kontaminasyonsebebi hem de emek isteyen bir uygulamadır (Fratamico ve ark., 2008). Ama bunlarla beraber PCR tekniği miktar ile ilgili tam anlamıyla bilgi vermemekte ve istenilen bilgiyisağlamamaktadır.

\section{REAL TIME PCR}

Real Time PCR teknolojisi ilk olarak Higuchi ve arkadaşlarının her bir amplifikasyon ürününü etidyum bromür ile görüntülemek için oluşturdukları sistem ile ortaya çıkmıştır (Higuchi ve ark.,1992). Bu teknolojifloresan işaretli ya da boyalı PCR ürünlerinin, 1şık kaynağının oluşturduğu 1şımalar ile uyarılması sonucu 1şıma yayması ve yaydığı 1şımaların algılanarak izlenebilir hale getirilmesi ile oluşan bir sistemdir. PCR'ın kinetik kazanması ile oluşan bu teknolojinin PCR'dan en önemli farkı hedef bölgenin lineer olarak logaritmik artışının eş zamanlı olarak gözlenebilmesi ve buna bağlı olarak kantitatif analiz yapabilme imkanı sunmasidır.

Real time PCR cihazı temel olarak 1sı döngü cihaz1, eksitasyon 1şık kaynağı, bir floresan algılama sistemi ve yazılımdan oluşmaktadır. Eksitasyon 1şı kaynağı argon-iyon lazerler, 1ş1k yayan diyot lazerler (LED), halojen lambalar ve ksenon lambalar olarak dört farklı çeşit olmakla birlikte en çok kullanılan 1şık kaynağ 1 lazerlerden ziyade halojen ve ksenon lambalardır (Valasek ve ark., 2005; Shipley, 2007). Lambalar LED ve lazerlere göre daha geniş spektrumlu olarak tanımlanmıştır (Valasek ve ark., 2005). Floresan algılama sistemi işaretlenmiş PCR ürünlerinin oluşturduğu floresan 1şımaları algılamakta ve bilgisayardaki yazılım ise bu verileri kaydetmektedir. Yüklenme-iliştirilmiş araç (CCD kamera), fotomultiplikatör tüpleri veya fotodedektörlerin diğer türlerini içeren bu sistem belirli sayılarda kanal içererek dalga boylarını sınırlayıp sadece tercih edilen dalga boylarının ölçülmesine izin vermektedir (Valasek ve ark., 2005). Yazılım verileri grafik olarak eş zamanlı görüntülemekte hem kalitatif hem de kantitatif analiz için floresan şiddetini sayısal değerlere dönüştürmektedir (Hanna ve ark., 2005).

$\mathrm{Bu}$ teknolojide floresan moleküllerin 1 şı kaynağından aynalar aracılığı ile üzerine gelen belirli dalga boyundaki ışınları absorbe ederek enerji kazanıp, bulundukları temel düzeyden uyarılmış düzeye geçmektedirler. Uyarılmış bu moleküller kararsız haldeki bu durumdan temel düzeye geçme eğiliminde oldukları için fazla enerjilerini farklı dalga boylarındaışımalar halinde yaymaktadır. Böylelikle floresan moleküllerin hem uyarıldıkları hem de yayıldıkları iki farklı dalga boyu aralıklarındaki ışımalar floresan algilama sistemi tarafindan belirlenmektedir (Shipley, 2007; Navarro ve ark.,2015). Real time PCR teknolojisinde kullanılan bu moleküllerin her birine özgü tanımlanmış farklı uyarılma ve yayılma dalga boyu aralıklarına sahiptir (Shipley, 2007).

Günümüzdeki Real time PCR cihazlarında floresan sinyaller farklı kanallar aracılığıyla floresan algılama sistemine iletilmektedir. Kanal sayısı özellikle çoklu PCR çalışmalarında farklı bölgeleri tanımlamak için önem taşımaktadır (Navarro ve ark.,2015). Real Time PCR teknolojisinde kalıp DNA'nın amplifikasyonu doğrusal zemin faz, erken üssel faz, üssel faz ve düz faz olarak 4 farklı fazda oluşmakta ve eş zamanlı izlenebilmektedir. Doğrusal zemin fazda PCR henüz başlamış ve floresan yayılmada artış gözlenmemektedir. Temel çizgi (baseline) hesaplaması bu aşamada yapılmaktadır. Erken üssel fazda floresan miktarı eşik değerine (treshold) ulaşmıştır. Eşik değerine denk gelen döngü sayısı eşik değeri döngüsü $(\mathrm{Ct})$ olarak bilinmektedir. $\mathrm{Bu}$ döngü değeri $\mathrm{ABI}$ literatürlerinde $\mathrm{Ct}$ olarak, LightCycler literatürlerinde ise geçiş noktası (Cp) olarak tanımlanmakta ve hedef bölgenin kopyalanmaya başladığını gösteren bir ifade olup analiz sonuçlarını hesaplamada kriter olarak kullanılmaktadır (Wong ve ark., 2005). Eşik değeri döngüsü hedef kopya sayıs1 ile ters orantılıdır ve kopya sayısı ne kadar fazla ise $\mathrm{Ct}$ değeri o kadar küçük olmaktadır (Schmittgen ve ark., 2008). Ct değeri bu nedenle kantitatif analizde önemli bir parametre özelliği taşımaktadır. Üssel faz aşamasında her döngü sonunda PCR ürünü ikiye katlanarak optimal amplifikasyon periyoduna ulaşmaktadır. Son olarak ise düz faz aşamasında reaksiyon bileşenleri sınırlı hale gelmiştir ve floresan yoğunluğu analiz verilerinihesaplamak için yeterli olmamaktadır (Wong ve ark., 2005).

\section{Real Time PCR'da Kullanılan Belirleme Teknolojileri}

Real Time PCR teknolojisinde esas olarak floresan sinyali oluşturan floresan işaretli moleküller kullanılmaktadır. Bu moleküller hedef diziye özgü işaretli oligonükleotitler ve hedef diziye özgü olmayan boyalar olarak iki gruba ayırmak mümkündür. Floresan 
sinyali oluşturan nükleik asit boyaları, taqman proplar, moleküler boncuk, akrep primerleri gibi farklı teknolojiler bulunmaktadır (Şekil 1). SYBR Green ve Taqman teknolojisi diğerlerine kıyasla birçok alanda oldukça yaygın bir şekilde kullanılmaktadır.

\section{SYBR Green Teknolojisi}

Nükleik asit boyaları, analiz sırasında çift zincirli DNA'ya bağlanarak floresan sinyal oluşturmaktadır. DNA'ya bağlanan bu boyalar arasında SYTO boyalar, EvaGreen ve SYBR Green yer almakla birlikte SYBR Green yaygın kullanılmaktadır. SYBR Green (2-[N-(3dimethylaminopropyl)-N-propylamino]-4-[2,3-dihydro3-methyl-(benzo-1,3-thiazol-2-yl)-methylidene]-1- phenylquinolinium) bir asimetrik siyanin boya olup çift zincirli DNA'nın küçük oluğuna bağlanmaktadırlar. Ayrıca analiz sırasında, her döngünün uzama safhasında eş zamanlı olarak ölçülebilmektedir. $\mathrm{Bu}$ boya bazlı algılama teknolojisi hedef diziye özgü olmadığından dolayı primer dimer oluşturabilmekte veya yanlış eşleşmiş PCR ürünlerine bağlanabilmektedir ve böylece yanlış pozitif sonuçların ortaya çıkmasına neden olmaktadır. Erime Eğrisi (Melting curve) analizi bu yanlış pozitif sonuçları belirlemek için geliştirilmiş bir uygulamadır. $\mathrm{Bu}$ uygulamada PCR sonrası oluşan tüm çift zincirli DNA'lara sicaklık uygulanarak erime noktaları belirlenmektedir

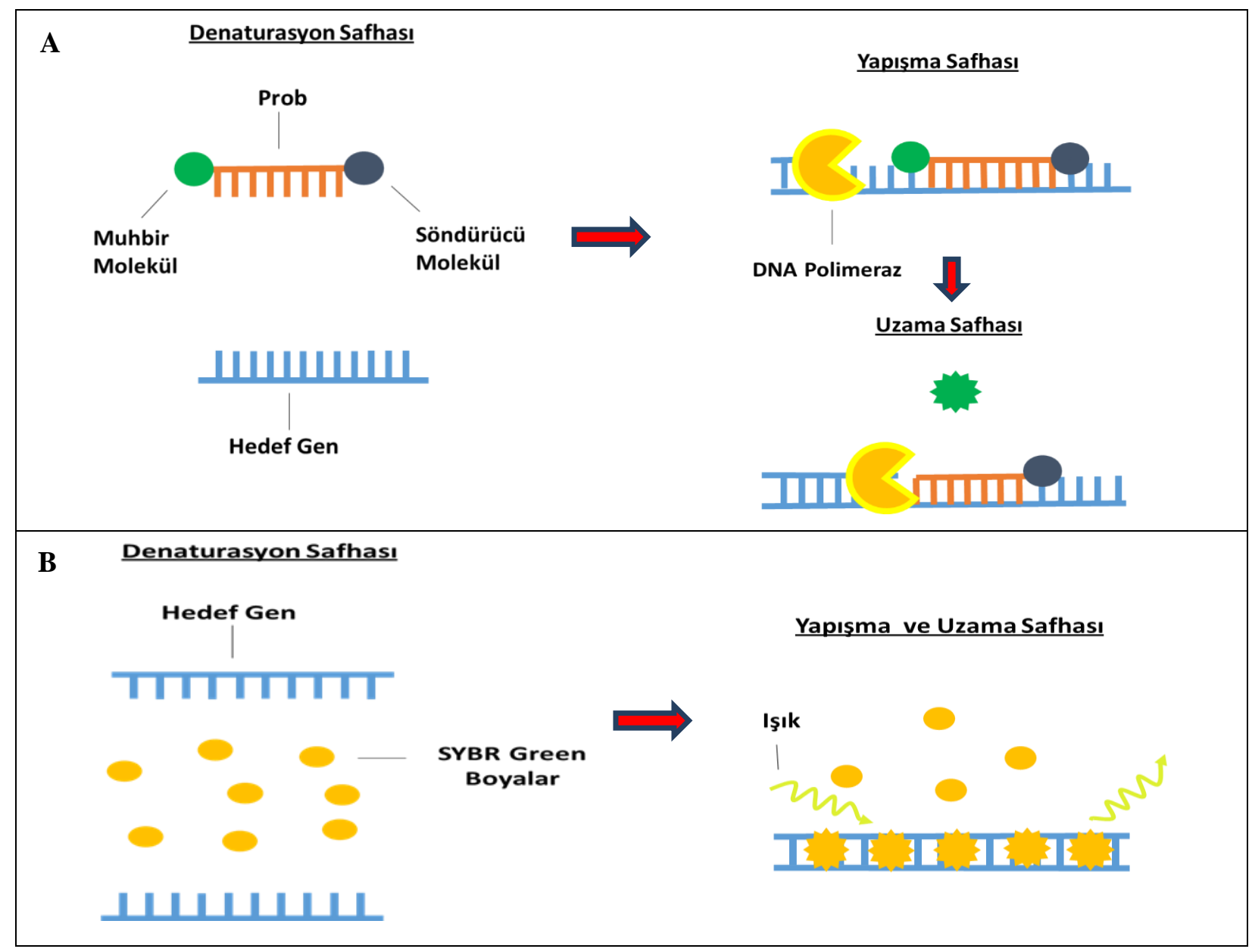




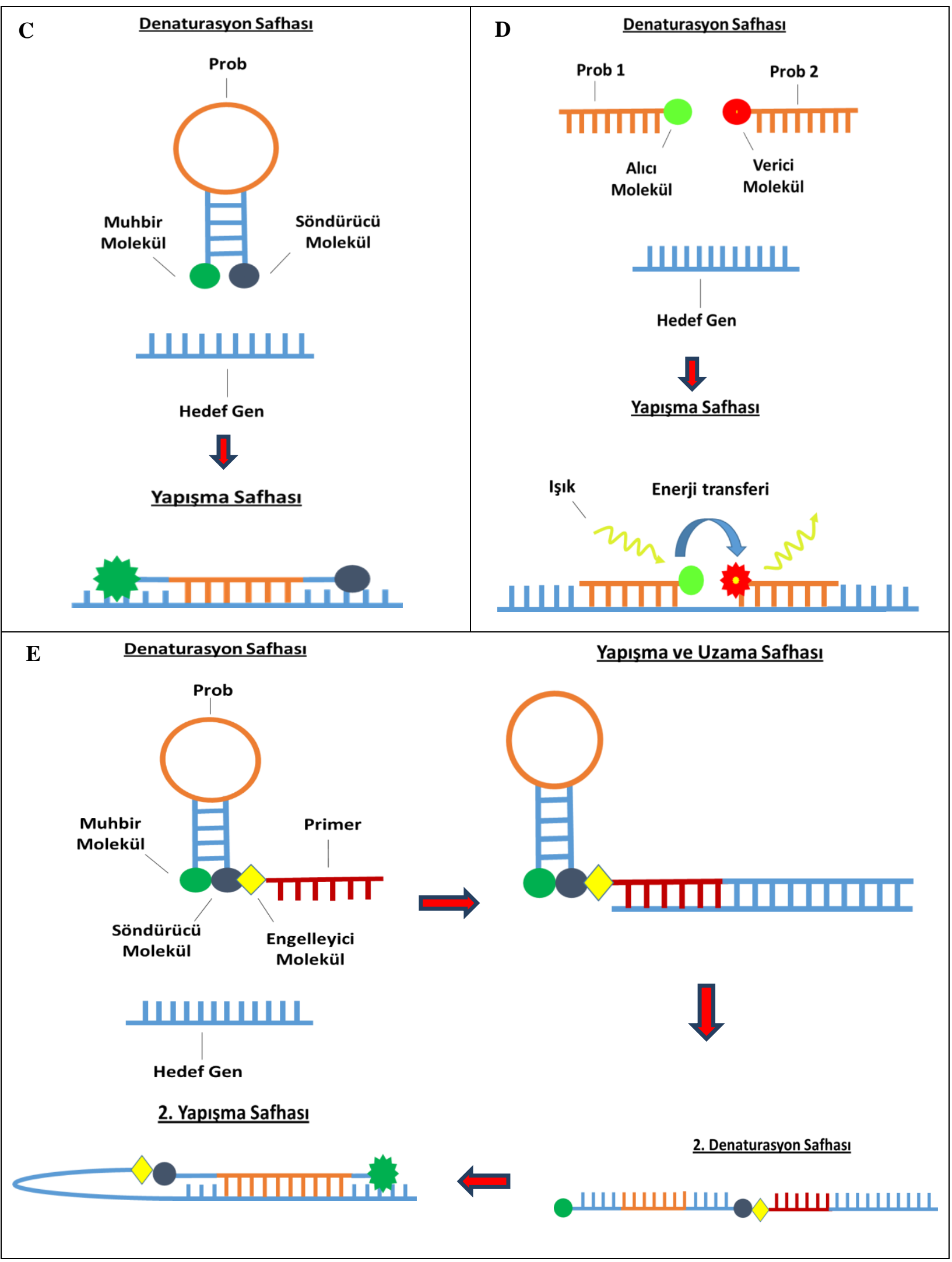

Şekil 1. Real Time PCR'da kullanılan belirleme teknolojilerinin çalışma mekanizmalarının şematik sunumu.

(A) Taqman Teknolojisi; Muhbir ve söndürücü molekülleri içeren prob hedef diziye bağlandıktan sonra DNA polimeraz enziminin aktivitesi ile muhbir molekül serbest kalarak floresan 1şıma yaymaktadır.

(B) SYBR Green Teknolojisi; SYBR Green boyalar çift zincirli DNA’ya bağlanarak floresan ışıma yaymaktadır. 
(C) Moleküler Boncuk Teknolojisi; Moleküler boncuk eşleniği olan diziye bağlandığında muhbir molekül floresan ışıma yaymaktadır.

(D) FRET Teknolojisi; Alıcı ve verici prob hedef diziye bağlandıktan sonra 1şığı absorbe eden alıcı prob ikinci probu uyarmakta ve üçüncü bir dalga boyunda floresan ışıma yayılmaktadır.

(E) Akrep Primerleri Teknolojisi; Primer bağlandıktan sonra uzama safhasında prob hedef diziye bağlanmaktadır. Böylelikle muhbir ve baskılayıcı molekül birbirinden ayrılarak floresan ışıma oluşmaktadır.

Daha uzun ve G/C oranı daha fazla olan DNA'ların erime noktaları daha yüksek olmasından dolayı primer dimer ve yanlış eşleşmiş DNA'lar belirlenebilmektedir (Buh Gašparič ve ark., 2010, Eischeid, 2011). SYBR Green teknolojisinin daha az maliyetli olması, daha güçlü floresan sinyal oluşturması avantajları arasında yer alırken dar dinamik aralığa sahip olması, PCR reaksiyonlarında yüksek konsantrasyonlarda inhibitör etkisi ve daha düşük tekrarüretilebilirlik göstermesi gibi sınırlamaları da bulunmaktadır. Bununla birlikte erime eğrisi analizlerinin yorumlanması da her zaman kolay olmamaktadır (Giglio ve ark., 2003, Eischeid, 2011). Son zamanlarda SYBR Green boyalara alternatif olarak Eva Green boyalar geliştirilmiştir. Üçüncü nesil boya olarak tanımlanan bu boyalar SYBR Green boyalardan daha stabil, daha hassas, daha az inhibitör etkisi sunmakta ve erime eğrisi analizlerine daha uygun olması ile daha çok tercih edilmektedir (Wang ve ark., 2006).

\section{Taqman Teknolojisi}

1991 yılında tanımlanan Taqman prob teknolojisi (Holland ve ark., 1991) hedef diziye özgü belirleme teknolojilerinden biri olup primere yakın bir dizinin komplemeterive 20-30 nükleotit (nt) uzunluğunda floresan özellik tanımlanmışoligonükleotitlerdir. DNA polimerazın 5' ekzonükleaz aktivitesinden dolayı hidroliz prob olarak da bilinmektedir. Bu teknolojide floresan işaretli moleküllerbelirlenen oligonükleotitlere bağlanmakta ve tepkime sırasında oluşturdukları 1şımalar ile algılanmaktadır.

Probların 5' ucunda muhbir olarak adlandirilan floresan boyalı bir molekül, 3' ucunda ise 5' ucundaki molekülün floresan 1şıma yaymasını baskılayan, söndürücü olarak adlandırılan floresan özellikli bir molekül bulunmaktadır. PCR'da probun kendi komplement bölgesine bağlanması ile DNA polimeraz 5' ekzonükleaz aktivitesini göstererek probu kırmaktadır. Dolayısı ile3' ucundaki baskılayıcı molekülden uzaklaşanfloresan işaretli $5^{\prime}$ floresan molekülü ışıma yaparak sinyal oluşturmaktadır (Mckillip ve Drake, 2004; Espy ve ark., 2006). Bununla beraber söndürücü olarak kullanılan moleküller her zaman belirlenebilir aralıkta floresan özellik taşımayabilir. DABSYL (4(dimethylamino)azobenzene-4'-sulfonyl chloride) veya BHQs (black hole quenchers) gibi söndürücü moleküller muhbir floroforları baskılayıp floroforun yaydığı 1şımayı absorblamakta ama kendisi floresan 1şıma yayma özelliği göstermemektedir. İdeal bir söndürücü molekülde aranan özellik söndürücünün absorbsiyon spektrumunun floroforun yayılma spektrumu ile örtüşmesidir. Bununla beraber söndürücü molekül en iyi absorbsiyonözelliğini maksimum absorbsiyona en yakın olduğu durumlarda göstermektedir. SYBR Green teknoloji ile karşılaştırıldığındaTaqman prob teknolojisi daha pahalı ve hedef bölgeye özgü olduğundan daha hassas bir metottur (Espy ve ark., 2006).

\section{Moleküler Boncuk Teknolojisi}

Bu moleküler teknolojide kullanılan problar 25-30 nt uzunluğunda, tek zincirli oligonükleotitlerdir ve nt dizisinin $5^{\prime}$ ve $3^{\prime}$ ucu yaklaşık 5-8 nt birbirinin prob üzerinde eşleniğiolmakla birlikte probun orta kısmındaki dizi ise hedef DNA dizinin eşleniğidir. Saç tokası şeklindeki bu yap1 Taqman prob gibi $5^{\prime}$ ucunda floresan 1şıma yapan bir muhbir molekül 3' ucunda ise bu 1şımayı baskılayan söndürücü bir molekül bulundurmaktadır. 5' ve 3'uçların birbirinin eşleniği olması 5' ucundaki molekülün 1şımasını engellemektedir. Moleküler boncuk probu kendine özgü DNA dizisineyapıştığında saç tokası şekli açılaraktek zincirli hale gelmekte ve $5^{\prime}$ ucundaki muhbir floresan ışıma yaymaktadır. Sonuçta yayılan floresan ışımaile kalitatif ve kantitatif analiz yapilabilmektedir. DNA amplifikasyonu sırasında moleküler boncukların yapısı bozulmadığından dolayı aynı prob her döngüde tekrar hedef diziye bağlanabilmektedir (Arya ve ark., 2005; Tyagi ve ark., 2012). Bu teknolojide moleküler boncuklar tek bir nükleotid farklılığında bile hedef DNA dizisinebağlanmayabilir. Hem avantaj hem de dezavantaj olarak kabul edilebilen bu özelliği ile SYBR Green ve Taqman prob teknolojilerinden daha hassas bir teknolojidir ve özellikle nokta mutasyonu çalışmalarında tercih edilmektedir (Abravaya ve ark., 2003).

\section{FRET Teknolojisi}

Light Cycler olarak da bilinen Floresan Rezonans Enerji Transferi (FRET) probları da diziye özgü prob teknolojileri arasında yer almaktadır. Light Cycler cihazlarında kullanılan bu teknolojide problar hibridisazyon probları olarak da adlandırılmaktadır. FRET teknolojisindehedef diziye özgü ve birbirlerine yakın olan iki prob tasarlanmış ve bir probun (verici prob) 3' ucunda floresan boya (genellikle FAM) diğer probun (alıcı prob) 5' ucunda ise başka bir floresan boya (genellikle siyanin boyalar, Cy3 ve Cy5 gibi) bulunmaktadır (Wilhelm ve ark., 2003). Problar hedef dizilere bağladıklarında 3' boyanın floresan 1şıması 5' ucundaki boya tarafindanbaskılanmaktadır. İkinci probun uyarılması ile üçüncü bir dalga boyunda ışıma 
yayılmakta ve bu ışıma ile floresan algılama gerçekleşmektedir. $\mathrm{Bu}$ teknoloji iki prob kullanıldığından hassas bir teknoloji olmakla birlikte özellikle mutasyon çalışmalarında kullanılmaktadır. Moleküler boncuk problarında olduğu gibi FRET problarıda kararlı bir yapıya sahip olup, PCR döngülerinde tekrar tekrar hedef diziye bağlanabilmektedirler (Espy ve ark., 2006).

\section{Akrep (Scorpian) Primer Teknolojisi}

Akrep (Scorpian) primer teknolojisi;tek bir molekülde hem primer hem de probdan oluşan boncuk teknolojisine benzersaç tokası şeklinde geliştirilmiştir (Whitcombe ve ark., 1999). Yapısal olarak sirasıly 5' ucunda muhbir bir florofor, probun 5' sap kısmı, ilmek bölgesi, 3' sap kısm1, 3' ucunda söndürücü bir florofor, engelleyici molekül (genellikle hekzilen glikol) ve primer bulunmaktadır. $5^{\prime}$ ve $3^{\prime}$ ucu birbirinin tamamlayıc1 olup ilmek bölgesi ise hedef diziyi tamamlayıcı özeliği taşımaktadır (Arya ve ark., 2005). Akrep primer teknolojisinde primer bağlandıktan sonra uzama safhasında prob hedef diziye bağlanmaktadır. Böylelikle muhbir ve baskılayıcı molekül birbirinden ayrılarak floresan 1şıma oluşmaktadır. Akrep primerlerde önemli noktalardan biri primer ve saç tokası yap1s1 arasında bulunan PCR engelleyici bir hekzilen glikol grup içermesidir. $\mathrm{Bu}$ engelleyici molekülün göreviakrep primerlerin saç tokası dizisinin uzamasını engellemektir (Kaltenboeck ve ark., 2005). Akrep primerleri hem primer hem saç tokası şeklinde prob içermelerinden dolayı daha hassas ve daha etkili analiz imkanı sunmaktadırlar. Genellikle de mutasyon çalışmalarında kullanılmaktadır (Arya ve ark., 2005).

\section{Real Time PCR'da Kantitatif Analiz}

Real time PCR'da kantitatif analizlerde genellikle mutlak (absolute) kantitasyon ve bağıl (relative) kantitasyon olmak üzere iki metot kullanılmaktadır (Arya ve ark., 2005). Mutlak kantitasyonda bir kalibrasyon eğrisi oluşturularak miktar tayini yapılabilmektedir. Kalibrasyon eğrisini oluşturan standartlar miktarı bilinen ve seyreltilerek farklı konsantrasyonlar oluşturulan PCR ürünleri, DNA molekülleri, RNA molekülleri, rekombinant plazmid DNA'sı veya ticari olarak sentezlenmiş oligonükleotitler olabilir (Pfafflve ark., 2001; Rasmussen 2001; Muska ve ark., 2007). Farklı konsantrasyondaki standartlar Real Time PCR cihazında analiz edilerek yazılım yardımı ile kalibrasyon eğrisi çizilmektedir. Kalibrasyon eğrisinin doğruluğu ve hassasiyeti standart olarak kullanılan referanslara bağlı olmaktadır. Bilinmeyen numunenin miktarı ise kalibrasyon eğrisine göre yazılım tarafindan hesaplanmaktadır. Kalibrasyon eğrisini oluşturan referans moleküller diş standart olarak tanımlanmaktadır. Bununla birlikte analizlerin doğruluğunu test etmek ve yanlış pozitif sonuçları engellemek amaçlı iç standartlarda (internal kontrol) kullanılmaktadır. Aynı reaksiyonda, aynı primerler ile kopyalanabilen iç standartlar korunmuş genler gibi canlıda doğal olarak bulunan dizilimlerdir (Selvey ve ark., 2001).

Bağıl kantitasyon (relative) veya karşılaştırmalı (comporative) kantitasyon ise genellikle gen ifade analizlerinde kullanılmaktadır. $\mathrm{Bu}$ metotta mutlak kantitasyonda olduğu gibi kalibrasyon eğrisi ve miktarı bilenen referans bir moleküle ihtiyaç duyulmamaktadır (Arya ve ark., 2005; Pfaffl, 2007). Bağıl kantitasyon analizlerinde referans kontrol veya kalibratörlerin ifade seviyeleri hedef genin ifade seviyesi ile karşılaştırılarak kantitatif analiz yapılmaktadır. Kalibratörler olarak tedavi görmemiş örnek, zaman noktası olarak başlangıç veya normal dokudan elde edilen RNA kullanılabilmekte ve dizisi bilinen herhangi bir transkript ise referans kontrol olabilmektedir (Pfaffl, 2007). Genellikle referans kontrol olarak korunmuş genler kullanılmaktadır. Bunlar hedef gen ile aynı tüpün içinde veya ayrı bir tüpte analiz edilebilmektedir. Korunmuş genler beta aktin, gliseraldehit 3 fosfat dehidrojenaz, glikolitik enzim veya ribozamal RNA gibi genler olabilir. (Huggett ve ark., 2006).

\section{GIDA KAYNAKLI MIKROBIYYAL PATOJENLERIN TANIMLANMASINDA REAL TIME PCR UYGULAMALARI}

Gıda kaynaklı mikrobiyal hastalıklara neden olan ajanların doğru, erken ve hızlı tanımlanması, enfeksiyona yakalanmış hastaların tedavi sürecinde en önemli faktörler arasında yer almaktadır. Kültürel, immünolojik ve PCR bazlı konvansiyonel metotlar Real Time PCR teknolojisine kiyasla istenilen hassasiyeti ve hızı sağlamamakla birlikte en önemlisi miktar ile ilgili yeterli bilgi sunmamaktadır. Real time PCR hassasiyeti, geniş bir dinamik aralığa sahip olması, özgüllüğü, hızı, kapalı bir sistem olması, PCR sonra uygulamalara gerek duyulmaması, kantitatif analiz imkanı sunması gibi avantajlarından dolayı konvansiyonel metotların birçok sınırlamalarını ortadan kaldırmıştır. Real time PCR teknolojisi sahip olduğu avantajlar ile birçok alanda kendine önemli bir yer edinmiş ve birçok gıda kaynaklı patojen mikroorganizmaların tanımlanmasında ve kantitatif analizinde kullanılmıştır (Bhagwat, 2003; Hadjinicolaou ve ark., 2009; Oliveira ve ark., 2010; Fukushima ve ark., 2010; Chen ve ark., 2010; Cheng ve ark., 2012; Jin ve ark., 2012; Elizaquível ve ark., 2012; Wang ve ark., 2012; Barbau-Piednoir ve ark., 2012). Farklı gidalarda, bazı mikrobiyal patojenlerin tanımlanmasında kullanılan gen bölgeleri, Real Time PCR teknolojileri ve belirleme limitleri Tablo 1'de verilmiştir.

Real Time PCR teknolojide mikrobiyal gida patojenlerini tanımlamada örnek hazırlama yöntemleriayrı bir önem taşımaktadır. Gıda örneklerinin çok fazla homojen olmaması ve hedef organizmaların sayısının az olması gibi zorluklar analiz öncesi zenginleştirme işlemi uygulanarak veya hedef 
organizmanın yoğunluğunu artırarak elemine edilebilmektedir (Hanna ve ark., 2005; Fratamico, 2008). $\mathrm{Bu}$ teknolojide kısa bir zenginleştirme uygulanarak bir kob/gr' a kadar belirleme limiti düşebilmekte ve özellikle gidalarda bulunan $E$. coli
O157:H7 ve Listeria monocytogenes gibi sifir toleransa sahip bakterileri belirlemede bile yüksek bir hassasiyet sunabilmektedir (Hanna ve ark., 2005).

Tablo 1. Farklı gıdalarda, bazı mikrobiyal patojenlerin tanımlanmasında kullanılan gen bölgeleri, Real Time PCR teknolojileri ve belirleme limitleri

\begin{tabular}{|c|c|c|c|c|c|c|}
\hline Mikroorganizma & Gıda Örneği & $\begin{array}{l}\text { Enfeksiyon } \\
\text { Dozu }\end{array}$ & $\begin{array}{l}\text { Hedef } \\
\text { Gen }\end{array}$ & $\begin{array}{l}\text { Real Time PCR } \\
\text { Teknolojisi }\end{array}$ & $\begin{array}{l}\text { Belirleme } \\
\text { Limiti }\end{array}$ & Kaynaklar \\
\hline $\begin{array}{l}\text { Aeromonas } \\
\text { hydrophila }\end{array}$ & Balık, Su & $10^{10} \mathrm{kob} / \mathrm{gr}$ & $\begin{array}{l}16 S \\
\text { rRNA } \\
\text { aerolysin } \\
\text { ast }\end{array}$ & $\begin{array}{l}\text { Taqman } \\
\text { SYBR Green }\end{array}$ & $\begin{array}{l}1 \mathrm{kob} / 10 \\
\mathrm{~mL}\end{array}$ & $\begin{array}{l}\text { Griffin ve } \\
\text { ark., } 2013 \\
\text { Trakhna ve } \\
\text { ark., } 2008 \\
\text { Trakhna ve } \\
\text { ark., } 2013\end{array}$ \\
\hline Bacillus cereus & $\begin{array}{l}\text { Sebze, } \\
\text { Yumurta } \\
\text { Hamburger, } \\
\text { Çiğ Süt, } \\
\text { Krema } \\
\end{array}$ & $\begin{array}{l}10^{5}-10^{9} \\
\mathrm{kob} / \mathrm{gr}\end{array}$ & $\begin{array}{l}16 S \\
r R N A \\
\text { gyrB } \\
\text { ces }\end{array}$ & $\begin{array}{l}\text { SYBR Green } \\
\text { Taqman }\end{array}$ & $\begin{array}{l}10^{4}-10^{5} \\
\mathrm{kob} / \mathrm{gr} \\
1.91 \times 10^{3} \\
\mathrm{kob} / \mathrm{mL}\end{array}$ & $\begin{array}{l}\text { Dzieciol ve } \\
\text { ark., } 2013 \\
\text { Ueda ve ark., } \\
2013\end{array}$ \\
\hline $\begin{array}{l}\text { Campylobacter } \\
\text { jejuni }\end{array}$ & Tavuk & $\begin{array}{l}10^{2}-10^{4} \\
\mathrm{kob} / \mathrm{gr}\end{array}$ & $\begin{array}{l}16 S \\
r R N A \\
\text { hipO } \\
\text { ccoN }\end{array}$ & $\begin{array}{l}\text { Taqman } \\
\text { Hibridizasyon }\end{array}$ & $\begin{array}{l}10^{1}-10^{4} \\
\text { kob/ } \mathrm{mL} \\
3 \times 10^{3} \\
\mathrm{kob} / \mathrm{mL} \\
>10 \\
\mathrm{kob} / \mathrm{mL}\end{array}$ & $\begin{array}{l}\text { Hong ve ark., } \\
2007 \\
\text { Toplak ve } \\
\text { ark., } 2011 \\
\text { Wolffs ve } \\
\text { ark., } 2007\end{array}$ \\
\hline $\begin{array}{l}\text { Clostridium } \\
\text { perfringens }\end{array}$ & Su, Et, Sebze & $\begin{array}{l}10^{7}-10^{9} \\
\mathrm{kob} / \mathrm{gr}\end{array}$ & $\begin{array}{l}\text { plc } \\
\text { cpa }\end{array}$ & Taqman & $10^{2} \mathrm{kob} / \mathrm{mL}$ & $\begin{array}{l}\text { Shannon ve } \\
\text { ark., } 2007 \\
\text { Chon ve ark., } \\
2012\end{array}$ \\
\hline $\begin{array}{l}\text { Cronobacter } \\
\text { sakazakii }\end{array}$ & Bebek Maması & $10^{3} \mathrm{kob} / \mathrm{gr}$ & $\begin{array}{l}m m s \\
\text { operon } \\
G \text { operon } \\
I A \\
\text { operon }\end{array}$ & $\begin{array}{l}\text { Taqman } \\
\text { SYBR Green }\end{array}$ & $\begin{array}{l}1.2 \times 10^{3} \\
\mathrm{kob} / \mathrm{mL} \\
10^{3} \mathrm{kob} / \mathrm{mL} \\
1.8 \times 10^{1} \\
\mathrm{kob} / \mathrm{mL}\end{array}$ & $\begin{array}{l}\text { Hyeon ve } \\
\text { ark., } 2010 \\
\text { Li ve ark., } \\
2006 \\
\text { Wang ve } \\
\text { ark., } 2012 \\
\end{array}$ \\
\hline E coli $\mathrm{O} 157: \mathrm{H} 7$ & $\begin{array}{l}\text { Peynir, Et, } \\
\text { Yoğurt, } \\
\text { Süt ve Süt } \\
\text { Ürünleri }\end{array}$ & $\begin{array}{l}10^{1}-10^{2} \\
\mathrm{kob} / \mathrm{gr}\end{array}$ & $\begin{array}{l}\text { stxl } \\
\text { stx } 2 \\
e a e \\
r f b E\end{array}$ & $\begin{array}{l}\text { Multiplex RT- } \\
\text { PCR } \\
\text { Taqman } \\
\text { LNA prob } \\
\text { Akrep primerleri }\end{array}$ & $\begin{array}{l}0.2 \mathrm{kob} / \mathrm{gr} \\
2.5 \times 10^{3} \\
\mathrm{kob} / \mathrm{mL} \\
1 \mathrm{kob} / 25 \\
\mathrm{~mL} \\
10^{3} \\
\mathrm{kob} / \mathrm{mL}\end{array}$ & $\begin{array}{l}\text { Köppel ve } \\
\text { ark., } 2013 \\
\text { Omiccioli ve } \\
\text { ark., } 2009 \\
\text { Sharma ve } \\
\text { ark., } 2000 \\
\text { Singh ve ark., } \\
2009\end{array}$ \\
\hline $\begin{array}{l}\text { Klebsiella } \\
\text { pneumoniae }\end{array}$ & Bebek Maması & $10^{8} \mathrm{kob} / \mathrm{gr}$ & phoE & $\begin{array}{l}\text { Taqman } \\
\text { SYBR Green }\end{array}$ & $1 \mathrm{kob} / 25 \mathrm{gr}$ & $\begin{array}{l}\text { Shannon ve } \\
\text { ark., } 2007 \\
\text { Sun ve ark., } \\
2010\end{array}$ \\
\hline
\end{tabular}


Tablo 1. Devamı

\begin{tabular}{|c|c|c|c|c|c|c|}
\hline Mikroorganizma & Gıda Örneği & $\begin{array}{l}\text { Enfeksiyon } \\
\text { Dozu }\end{array}$ & $\begin{array}{l}\text { Hedef } \\
\text { Gen }\end{array}$ & $\begin{array}{l}\text { Real Time PCR } \\
\text { Teknolojisi }\end{array}$ & $\begin{array}{l}\text { Belirleme } \\
\text { Limiti }\end{array}$ & Kaynaklar \\
\hline $\begin{array}{l}\text { Listeria } \\
\text { monocytogenes }\end{array}$ & $\begin{array}{l}\text { İşlenmiş Gıda } \\
\text { Örnekleri, } \\
\text { Peynir, Yoğurt, } \\
\text { Et, Süt }\end{array}$ & $\begin{array}{l}10^{2}-10^{3} \\
\mathrm{kob} / \mathrm{gr}\end{array}$ & $\begin{array}{l}\text { hlyA } \\
\text { hlyQ } \\
\text { ssrA }\end{array}$ & $\begin{array}{l}\text { Multiplex RT- } \\
\text { PCR } \\
\text { Taqman } \\
\text { FRET } \\
\text { LNA prob }\end{array}$ & $\begin{array}{l}<10 \\
\mathrm{kob} / \mathrm{mL} \\
1 \mathrm{kob} / \mathrm{gr} \\
1-5 \mathrm{kob} / 25 \\
\mathrm{gr} \\
1 \mathrm{kob} / 25 \\
\mathrm{~mL}\end{array}$ & $\begin{array}{l}\text { Garrido ve } \\
\text { ark., } 2012 \\
\text { Köppel ve } \\
\text { ark., } 2013 \\
\text { O’Grady ve } \\
\text { ark., } 2008 \\
\text { Omiccioli ve } \\
\text { ark., } 2009\end{array}$ \\
\hline $\begin{array}{l}\text { Salmonella } \\
\text { enterica }\end{array}$ & $\begin{array}{l}\text { İşlenmiş Gıda } \\
\text { Örnekleri, } \\
\text { Peynir, Yoğurt, } \\
\text { Et, Kümes } \\
\text { Hayvanları, } \\
\text { Yumurta }\end{array}$ & $\begin{array}{l}10^{0}-10^{9} \mathrm{kob} \\
\operatorname{lgr}\end{array}$ & $\begin{array}{l}i n v A \\
t t r\end{array}$ & $\begin{array}{l}\text { Multiplex RT- } \\
\text { PCR } \\
\text { Taqman } \\
\text { SYBR Green }\end{array}$ & $\begin{array}{l}<10 \\
\mathrm{kob} / \mathrm{mL} \\
0,05 \mathrm{kob} / \mathrm{gr} \\
10^{0}-10^{1} \\
\mathrm{kob} / 25 \mathrm{gr} \\
10^{3} \mathrm{kob} / \mathrm{mL}\end{array}$ & $\begin{array}{l}\text { Cheng ve } \\
\text { ark., } 2012 \\
\text { Delibato ve } \\
\text { ark., } 2011 \\
\text { Garrido ve } \\
\text { ark., } 2012 \\
\text { Hyeon ve } \\
\text { ark., } 2010 \\
\text { Köppel ve } \\
\text { ark., } 2013 \\
\text { Malorny ve } \\
\text { ark., } 2004\end{array}$ \\
\hline $\begin{array}{l}\text { Staphylococcus } \\
\text { aureus }\end{array}$ & $\begin{array}{l}\text { Süt } \\
\text { Et, Peynir, } \\
\text { Krema, } \\
\text { Sebze }\end{array}$ & $\begin{array}{l}10^{5}-10^{8} \\
\mathrm{kob} / \mathrm{gr}\end{array}$ & $\begin{array}{l}\text { nuc } \\
\text { htrA } \\
\text { oriC }\end{array}$ & $\begin{array}{l}\text { Taqman } \\
\text { SYBR Green }\end{array}$ & $\begin{array}{l}10 \mathrm{kob} / \mathrm{mL} \\
5 \times 10^{2} \mathrm{kob} / \\
\mathrm{gr} \\
10^{3} \mathrm{kob} / \mathrm{gr} \\
10^{3} \mathrm{kob} / \mathrm{gr}\end{array}$ & $\begin{array}{l}\text { Alarcon ve } \\
\text { ark., } 2006 \\
\text { Chiang ve } \\
\text { ark., } 2007 \\
\text { Elizaquivel ve } \\
\text { ark., } 2008 \\
\text { Hein ve ark., } \\
2005\end{array}$ \\
\hline $\begin{array}{l}\text { Yersinia } \\
\text { enterocolitica }\end{array}$ & $\begin{array}{l}\text { Süt, Balık, Et, } \\
\text { Sucuk }\end{array}$ & $10^{8} \mathrm{kob} / \mathrm{gr}$ & ail & Taqman & $10^{1} \mathrm{kob} / \mathrm{gr}$ & $\begin{array}{l}\text { Lambertz ve } \\
\text { ark., } 2008\end{array}$ \\
\hline
\end{tabular}

Yapılan bir çalışmada gıda örneklerinde $E$. coli'nin varlığı zenginleştirme yapılmadan $10^{3}-10^{9} \mathrm{hücre} / \mathrm{gr}$ aralığında bulunurken zenginleştirme uygulaması ile belirleme limitinin $10^{3}$ hücre/gr'ınaltına düştüğü tespit edilmiştir (Takahashi ve ark., 2009).Bu uygulama ile süt örneğinde Salmonella enterica'nın belirleme limiti2-6 saatlikinkubasyonda belirlenemezken 8-12 saatlikinkubasyonda $2.3-2.3 \times 10^{2} \mathrm{kob} / 10 \mathrm{ml}$ arasinda değişiklik göstermiş ve en düşük belirleme limiti 12 saatlik inkubasyon süresi sonunda elde edilmiştir (Liu ve ark., 2012). Bunlarla beraber Real Time PCR teknolojisinde canlı ve ölü hücreleri ayırma işlemindeki sınırlamalar örneklerin hazırlık aşamasında Etidyum monoazit ve propidyum monoazit gibi bileşikler kullanılması ile ortadan kalkmaktadır (Shi ve ark., 2012; Elizaquívela ve ark., 2012; Minami ve ark., 2012; Liu ve ark., 2014). Ayrıca örneklerde veya örneklerin hazırlık aşamasında oluşabilecek inhibisyonların etkisini belirlemek amaçlı iç kontrol standartlar kullanılmakta ve böylelikle tepkime sırasında oluşabilecek yanlış negatif sonuçlar engellenmektedir (Selvey ve ark., 2001).
Gida kaynaklı patojen mikroorganizmaları tanımlamada Real Time PCR'da kullanılan belirleme teknolojileri arasında en yaygın olarak SYBRGreen ve Taqman teknolojileri kullanılmaktadır. Yapılan bir araştırmada E. coli $\mathrm{O} 157: \mathrm{H} 7$, Listeria monocytogenes ve Salmonella suşlarını tanımlamak amacıylaSYBR Green I teknolojisi kullanılmıştır. En düşük belirleme limiti E. coli O157:H7 ve Salmonella türleri için 1 hücre/ml olarak tespit edilirken Listeria monocytogenes için ise bu limit $10^{1}$ hücre $/ \mathrm{ml}$ olarak belirtilmiştir (Bhagwat, 2003). Bununla beraber Listeria monocytogenes, Salmonella spp., ve Campylobacter jejuni gibi bir çok gıda kaynaklı patojen mikroorganizmalar SYBR Green tekniği ile belirlenmiş̧iir (De Medici ve ark., 2003; Nam ve ark., 2005; Fukushima ve ark., 2010; Delibato ve ark., 2011; Barbau-Piednoir ve ark., 2012).

Taqman teknolojisi Real Time PCR uygulamalarında en çok tercih edilen belirleme teknolojisi özelliği taşımaktadır. Fırsatçı bir gıda patojeni olanCronobacter sakazakii Real Time PCR çalışmalarında hedef organizmalar arasında yer almaktadır. $\mathrm{Bu}$ firsatçı patojenin tanımlanması ve 
gıdalarda bulunma miktarının tespit edilmesi için geliştirilen bir Real Time PCR metodunda Taqman PCR teknolojisi kullanılmıştır. Geliştirilen bu metotta analizin hassasiyetini ve özgüllügünü artırmak amacıyla Taqman probları kullanılmıştır. Zenginleştirme yapılmadan saf kültür ve bebek mamasında tespit limiti $1.210^{3} \mathrm{kob} / \mathrm{ml}\left(1.210^{1} \mathrm{kob} /\right.$ test $)$ olduğu ve yapay olarak kontamine olmuş gıdalarda 24 saat zenginleştirme sonras 1 ise $10^{1} \mathrm{kob} / \mathrm{ml}$ veya g Cronobacter varlığının tespit edilebildiği belirtilmiştir (Wang ve ark., 2012 ). Taqman teknoloji kullanılarak birçok gıda kaynaklı hastalık etmeni mikroorganizmalar tanımlanmış ve gıdalarda varlığı tespit edilmiştir (Seo ve ark., 2005; Kagkli ve ark., 2011; Leblanc-Maridor ve ark., 2011).

Et ve et ürünleri, süt ve süt ürünleri, sebzeler gibi gıda örnekleri birden fazla patojen içerebilmektedir. Bu gibi durumlarda çoklu patojen tanımlaması çoklu Real Time PCR teknoloji ile çok daha hızlı, daha duyarlı ve daha ekonomik bir alternatif yöntem olarak sunulmaktadır (Garrido ve ark., 2013). Ancak tek bir reaksiyonda kullanılan primer çiftleri, kalıp DNA'lar ve problar analiz sırasında inhibitör etki gösterebilir ve yanlış ya da çıkmayan sonuçlara neden olabilmektedir (Arya ve ark., 2005). Bu yüzden çoklu Real Time PCR analizlerinde optimizasyon ayrıca bir önem taşımaktadır. Huang ve ark., (2007) yaptığı bir çalışmada Shigella spp., E. coli O157:H7, Vibrio cholerae, Vibrio parahaemolyticus ve Streptococcus pyogenes patojen mikroorganizmalarında içinde yer aldığı toplam 8 patojen için moleküler boncuk teknolojisi kullanılarak yeni bir Multiplex Real Time PCR metodu geliştirilmiş ve toplamda 118 gida izolatları ve klinik izolatları analiz edilerek metot valide edilmiştir. Tek bir reaksiyonda 8 çift primer, 8 çift moleküler boncuk ve 1 çiftte üniversal primer kullanılmış hedef genleri için hiçbir yanlış pozitif veya negatif sonuç elde edilmediği belirtilmiştir.

Sonuç olarak gıda kaynaklı mikrobiyal hastalıklar küresel boyutta bir tehdit oluşturmakta, ciddi sağlık problemleri ile beraber ciddi ekonomik kayıplara yol açmaktadır. Bu nedenle hastalıkların önüne geçebilmek ve hastalık etkenlerini tanımlamak büyük önem taşımaktadır. Real Time PCR teknolojisi patojen mikroorganizmaları belirlemek ve karakterize etmek amaciyla uygulanmakta ve diğer teknolojilere göre oldukça duyarlı, özgül, hızlı, dedeksiyon limiti düşük ve kontaminasyon riski az bir teknolojidir.Önemli bir halk sağlığı sorunu olan gida kaynaklı mikrobiyal hastalıkların etkenlerini tespit etmek ve önlemek için umut verici bir potansiyele sahip olduğu düşünülmektedir.

\section{KAYNAKLAR}

Abravaya, K., Huff, J., Marshall, R., Merchant, B., Mullen, C., Schneider, G., Robinson, J. 2003. Molecular beacons as diagnostic tools: technology and applications. Clin. Chem. Lab. Med., 41(4): 468-474.
Alarcon, B., Vicedo, B., Aznar, R., 2006. PCR-based procedures for detection and quantification of Staphylococcus aureus and their application in food. J. Appl. Microbiol., 100: 352-364.

Arya, M., Shergill, I. S., Williamson, M., Gommersall, L., Arya, N., Patel, H. R. 2005. Basic principles of real-time quantitative PCR. Expert Review of Molecular Diagnostics, 5(2): 209-219.

Aytac, S.A., Taban, B.M. 2014. Food-Borne Microbial Diseases and Control: Food-Borne Infections and Intoxications. (Food Processing: Strategies for Quality Assessment, Springer Publishers, New York: Ed. Malik, A., Erginkaya, Z., Ahmad, S., Erten, H.) 191-224.

Barbau-Piednoir, E., Botteldoorn, N., Yde, M., Mahillon, J., Roosens, N. H. 2012. Development and validation of qualitative SYBR ${ }^{\circledR}$ Green Real-Time PCR for detection and discrimination of Listeria spp. and Listeriamonocytogenes. Applied Microbiology and Biotechnology, 97(9): 4021-4058.

Beneduce, L., Fiocco, D., Spano, G. 2007. Development of PCR-based molecular tools for the detection of emerging food-ad water-borne pathogenic bacteria. Communicating Current Research and Educational Topics and Trends in Applied Microbiology,

Bhagwat, A.A. 2003. Simultaneous detection of Escherichia coli O157: H7, Listeriamonocytogenes and Salmonella strains by real-time PCR. International Journal of Food Microbiology, 84(2): 217-224.

Bhunia, A.K. 2008. Foodborne Microbial Pathogens Mechanisms and Pathogenesis. Springer Publishers, New York, 276s.

Botteroa, M.T., Dalmassoa, A., Sogliab, D., Rosatib, S., Decastellic, L., Civera, T. 2004. Development of a multiplex PCR assay for the identification of pathogenic genes of Escherichia coli in milk and milk products. Molecular and Cellular Probes, 18: 283-288.

Buh Gasparic, M., Tengs, T., La Paz, J.L., Holst-Jensen, A., Pla, M., Esteve, T., Zel, J., Gruden, K. 2010. Comparison of nine different real-time PCR chemistries for qualitative and quantitative applications in GMO detection. Anal Bioanal Chem., 396(6): 2023-2029.

Cawthorn, D. M., Botha, S., Witthuhn, R. C. 2008. Evaluation of different methods for the detection and identification of Enterobacter sakazakii isolated from South African infant formula milks and the processing environment. International Journal of Food Microbiology, 127(1): 129-138.

Chen, Y., Song, K. Y., Brown, E. W., Lampel, K. A. 2010. Development of an improved protocol for the isolation and detection of Enterobacter sakazakii (Cronobacter) from powdered infant formula. Journal of Food Protection, 73(6): 1016-1022. 
Cheng, C. Y., Huang, M. J., Chiu, H. C., Liou, S. M., Chou, C. C., Huang, C. C. 2012. Simultaneous Detection of Food Pathogens, Staphylococcus aureus, Salmonella enterica, Bacilluscereus and Vibrioparahaemolyticus by Multiplex Real-Time Polymerase Chain Reaction. Journal of Food and Drug Analysis, 20(1): 66-73.

Cheng, C. Y., Huang, M. J., Chiu, H. C., Liou, S. M., Chou, C. C., Huang, C. C. 2012. Simultaneous Detection of Food Pathogens, Staphylococcus aureus, Salmonellaenterica, Bacillus cereus and Vibrio parahaemolyticus by Multiplex Real-Time Polymerase Chain Reaction. Journal of Food and Drug Analysis, 20(1): 66-73.

Chiang, Y.C., Fan, C.M., Liao, W.W., Lin, C.K., Tsen, H.Y., 2007. Real-time PCR detection of Staphylococcus aureus in milk and meat using new primers designed from the heat shock protein gene htrA sequence. J. Food Prot., 70: 2855-2859.

Chon, J.W., Park, J.S., Hyeon, J.Y., Park, C., Song, K.Y., Hong, K.W., Hwang, I.G., Kwak, H.S., Seo, K.H. 2012. Development of real-time PCR for the detection of Clostridiumperfringens in meats and vegetables. J Microbiol Biotechnol., 22(4): 530-534.

De Medici, D., Croci, L., Delibato, E., Di Pasquale, S., Filetici, E., Toti, L. 2003. Evaluation of DNA Extraction Methods for Use in Combination with SYBR Green I Real-Time PCR To Detect Salmonellaenterica Serotype enteritidis in Poultry. Applied and Environmental Microbiology, 69(6): 3456-3461.

Delibato, E., Fiore, A., Anniballi, F., Auricchio, B., Filetici, E., Orefice, L., Losio, M.N., De Medici, D. 2011. Comparison between two standardized cultural methods and 24 hour Duplex SYBR Green Real-Time PCR assay for Salmonella detection in meat samples. New microbiologica, 34(3): 299-306.

Dzieciol, M., Frickerb, M., Wagner M., Heina, I., Ehling-Schulzb, M. 2013. A novel diagnostic realtime PCR assay for quantification and differentiation of emetic and non-emetic Bacillus cereus. Food Control, 32(1): 176-185.

Eischeid, A. C. 2011. SYTO dyes and EvaGreen outperform SYBR Green in real-time PCR. BMC Research Notes, 4: 263.

Elizaquivel, P., Aznar, R., 2008. A multiplex RTi-PCR reaction for simultaneous detection of Escherichia coli O157:H7, Salmonella spp. and Staphylococcus aureus on fresh, minimally processed vegetables. Food Microbiol., 25: 705-713.

Elizaquivel, P., Sanchez, G., Aznaret, R. 2012. Quantitative detection of viable foodborne E. coli O157:H7, Listeriamonocytogenes and Salmonella in fresh-cut vegetables combining propidium monoazide and real-time PCR. Food Control, 25(2): 704-708.
Espy, M.J., Uhl, J.R., Sloan, L.M., Buckwalter, S.P., Jones, M.F., Vetter, E.A., Yao, J.D.C., Wengenack, N.L., Rosenblatt, J.E., Cockerill, F.R., Smith, T.F. 2006. Real-time PCR in clinical microbiology: applications for routine laboratory testing. Clinical Microbiology Reviews, 19(1):165-256.

Fratamico, P. M., Kawasaki, S. 2008. Applications of the polymerase chain reaction for detection, identification, and typing of foodborne microorganisms. (Microbial Food Contamination, CRC Press Publishers, New York: Ed. Wilson, C. L.) 213-254.

Fukushima, H., Kawase, J., Etoh, Y., Sugama, K., Yashiro, S., Lida, N., Yamaguchi, K. 2010. Simultaneous screening of 24 target genes of foodborne pathogens in 35 foodborne outbreaks using multiplex Real-Time SYBR Green PCR analysis. International Journal of Microbiology, 2010(2010): 18s.

Garrido, A., Chapela, M., Román, B., Fajardo, P., Lago, J., Vieites, J.M., Cabado, A.G. 2013. A new multiplex real-time PCR developed method for Salmonella spp. and Listeria monocytogenes detection in food and environmental samples. Food Control, 30: 76-85.

Garrido, A., Chapela, M.J., Román, B., Ferreira, M., Lago, J., Vieites, J.M.,Cabado, A.G. 2012. Development of a multiplex real-time PCR method for simultaneous detection of Salmonella enterica, Shigella xexneri and Listeria monocytogenes in processed food samples. Eur. Food Res. Technol., 234:571-580.

Giglio, S., Monis, P.T., Saint, C.P. 2003. Demonstration of preferential binding of SYBR Green I to specific DNA fragments in real-time multiplex PCR. Nucleic Acids Res., 31(22): e136.

Griffin, M.J., Goodwin, A.E., Merry, G.E., Liles, M.R., Williams, M.A., Ware, C., Waldbieser, G.C. 2013. Rapid quantitative detection of Aeromonas hydrophila strains associated with disease outbreaks in catfish aquaculture. Journal of Veterinary Diagnostic Investigation, 25(4): 473-481.

Hadjinicolaou, A.V., Demetriou, V.L., Emmanuel, M.A., Kakoyiannis, C.K., Kostrikis, L.G. 2009. Molecular beacon-based real-time PCR detection of primary isolates of SalmonellaTyphimurium and SalmonellaEnteritidis in environmental and clinical samples. BMC Microbiology, 9(1): 97.

Hanna, S.E., Connor, C.J., Wang, H.H. 2005. Real time Polymerase Chain Reaction for the Food Microbiologist: Technologies, Applications, and Limitations. Journal of Food Science, 70(3): 49-53.

He, Y., Chen, C. 2010. Quantitative analysis of viable, stressed and dead cells of Campylobacterjejuni strain 81-176. Food Microbiology, 27(4): 439-446. 
Hein, I., Jørgensen, H.J., Loncarevic, S., Wagner, M. 2005. Quantification of Staphylococcus aureus in unpasteurised bovine and caprine milk by real-time PCR. Research in Microbiology, 156: 554-563.

Higuchi, R., Dollinger, G., Walsh, P.S., Griffith, R. 1992. Simultaneous amplification and detection of specific DNA sequences. Biotechnology, 10(4): 413417.

Hill, W.E., Wachsmuth, K. 1996. The polymerase chain reaction: applications for the detection of foodborne pathogens. Critical Reviews in Food Science and Nutrition, 36(1-2). 123-173.

Holland, P.M., Abramson, R.D., Watson, R., Gelfand, D.H. 1991. Detection of specific polymerase chain reaction product by utilizing the $5^{\prime}-3^{\prime}$ exonuclease activity of Thermus aquaticus DNA polymerase. Proc Natl Acad Sci., 88:7276-80.

Hong, J., Jung, W.K., Kim, J.M., Kim, S.H., Koo, H.C., Ser, J., Park, Y.H. 2007. Quantification and differentiation of Campylobacter jejuni and Campylobacter coli in raw chicken meats using a real-time PCR method. J. Food Prot., 70: 2015-2022.

Huang, Q., Hu, Q., Li, Q. 2007. Identification of 8 Foodborne Pathogens by Multicolor Combinational Probe Coding Technology in a Single Real-Time PCR. Clin Chem., 53(10):1741-1748.

Huggett, J., Dheda, K., Bustin, S.A. 2007. Normalization in Real-time PCR. (Real-time PCRTaylor and Francis Group Publishers, New York: Ed. Dorak, M.T.) 83-91.

Hyeon, J., Park ,C., Choi, I., Holt, P.S., Seo, K. 2010. Development of multiplex real-time PCR with Internal amplification control for simultaneous detection of Salmonella and Cronobacter in powdered infant formula. International Journal of Food Microbiology, 144(2010): 177-181.

Jasson, V., Jacxsens, L., Luning, P., Rajkovic, A., Uyttendaele, M. 2010. Alternative microbial methods: an overview and selection criteria. Food Microbiology, 27(6): 710-730.

Jin, D., Luo, Y.,L., Zhang, Z., Fang, W., Ye, J., Wu, F., Ding, G. 2012. Rapid molecular identification of Listeria species by use of real-time PCR and highresolution melting analysis. FEMS Microbiology Letters, 330(1): 72-80.

Kagkli, D., Weber, T.P., Bulcke, M., Folloni, S., Tozzoli, R., Morabito, S., Ermolli, M., Gribaldo, L., Van den Eede, G. 2011. Application of the Modular Approach to an In-House Validation Study of RealTime PCR Methods for the Detection and Serogroup Determination of Verocytotoxigenic Escherichia coli. Appl Environ Microbiol., 77(19): 6954-6963.

Kaltenboeck, B., Wang, C. 2005. Advances in real-time PCR: Application to clinical laboratory diagnostics. Advances in Clinical Chemistry, 40: 219-259.
Köppel, R., Kuslyte, A.R., Tolido, I., Schmid, J., Marti, G. 2013. Nonaplex real-time PCR detection of Listeria monocytogenes, Campylobacter, Salmonella and enteropathogene E. coli after universal enrichment in food samples. Eur Food Res Technol., 237:315-322.

Lambertz, S.T, Nilsson, C., Hallanvuo, S., Lindblad, M. 2008. Real-Time PCR Method for Detection of Pathogenic Yersinia enterocolitica in Food. Applied and Environmental Microbiology, 74: 6060-6067.

Leblanc-Maridor, M., Garénaux, A., Beaudeau, F., Chidaine, B., Seegers, H., Denis, M., Belloc, C. 2011. Quantification of Campylobacter spp. in pig feces by direct real-time PCR with an internal control of extraction and amplification. J Microbiol Methods, 85(1): 53-61.

Lindqvist, R. 1999. Detection of Shigella spp. in food with a nested PCR method-sensitivity and performance compared with a conventional culture method. Journal of Applied Microbiology, 86(6): 971-978.

Liu, B., Zhou, X., Zhang, L., Liu, W., Dan, X., Shi, C., Shi, X. 2012. Development of a novel multiplex PCR assay for the identification of Salmonellaenterica Typhimurium and Enteritidis. Food Control, 27: 87-93.

Liu, Y., , Cai, X., , Zhang, X., Gao, Q., Yang, X., Zhenga, Z., Luo, M., Huang, X. 2006. Real time PCR using TaqMan and SYBR Green for detection of Enterobacter sakazakii in infant formula. Journal of Microbiological Methods, 65: 21-31.

Liu, Y., Mustapha, A. 2014. Detection of viable Escherichiacoli $\mathrm{O} 157: \mathrm{H7}$ in ground beef by propidium monoazide real-time PCR. Int J Food Microbiol., 170: 48-54.

Malorny, B., Paccassoni, E., Fach, P., Bunge, C., Martin, A., Helmuth, R., 2004. Diagnostic real-time PCR for detection of Salmonella in food. Applied and Environmental Microbiology, 70(12): 70467052.

Malorny, B., Tassios, P. T., Radström, P., Cook, N., Wagner, M., Hoorfar, J. 2003. Standardization of diagnostic PCR for the detection of foodborne pathogens. International Journal of Food Microbiology, 83(1): 39-48.

Mckillip, J. L., Drake, M. 2004. Real-time nucleic acidbased detection methods for pathogenic bacteria in food. Journal of Food Protection, 67(4): 823-832.

Minami, J., Soejima, T., Yaeshima, T., Iwatsuki, K. 2012. Direct Real-Time PCR with Ethidium Monoazide: A Method for the Rapid Detection of Viable Cronobactersakazakii in Powdered Infant Formula. J. Food Prot., 75(9): 1572-1579. 
Muska, A., Peck, E., Palmer, S. 2007. Standards and Controls: Concepts for Preparation and Use in Realtime PCR Applications. ( Real-Time PCR in Microbiology From Diagnosis to Characterization, Caister Academic Press Norfolk, UK: Ed. Mackay, I.M.) 101-132.

Nam, H.M., Srinivasan, V., Gillespie, B.E., Murinda, S.E., Oliver, S.P. 2005. Application of SYBR green real-time PCR assay for specific detection of Salmonella spp. in dairy farm environmental samples. International Journal of Food Microbiology, 102(2):161-171.

Navarro, E., Serrano-Heras, G., Castañoa, M.J., Solera, J. 2015. Real-time PCR detection chemistry. Clinica Chimica Acta, 439: 231-250.

O' Grady, J., Sedano-Balbás, S., Maher, M., Smith, T., Barry, T. 2008. Rapid real-time PCR detection of Listeria monocytogenes in enriched food samples based on the ssrA gene, a novel diagnostic target. Food Microbiol., 25(1):75-84.

Oliveira, M.A., Ribeiro, E.G.A., Bergamini, A.M.M., Martinis, E.C.P. 2010. Quantification of Listeria monocytogenes in minimally processed leafy vegetables using a combined method based on enrichment and 16S rRNA real-time PCR. Food Microbiology, 27(1): 19-23.

Omiccioli, E., Amagliani, G., Brandi, G., Magnani, M. 2009. A new platform for real-time PCR detection of Salmonella spp., Listeria monocytogenes and Escherichia coli $\mathrm{O} 157$ in milk. Food Microbiol., 26(6):615-622.

Pfaffl, M.W. 2007. Relative quantification. (Real-time PCR, Taylor and Francis Group Publishers, New York: Ed. Dorak, M.T.) 63-82.

Pfaffl, M.W., Hageleit, M. 2001. Validities of mRNA quantification using recombinant RNA and recombinant DNA external calibration curves in real-time RT-PCR. Biotechnology Letters, 23: 275282.

Pinto, B., Chenoll, E., Aznar, R. 2005. Identification and typing of food-borne Staphylococcus aureus by PCR-based techniques. Systematic and Applied Microbiology, 28(4): 340-352.

Rasmussen, R. 2001. Quantification on the lightCycier. (Rapid Cycle Real-Time PCR Methods and Applications, Springer Publishers, Berlin: Ed. Meuer, S., Wittwer, C., Nakagawara, K.) 21-34.

Rijpens, N.P., Herman, L.M.F. 2002. Molecular Methods for Identification and Detection of Bacterial Food Pathogens. Journal Of AOAC International, 85(4): 984-995.

Ripabelli, G., McLauchlin, J., Mithani, V., Threlfall, E.J. 2000. Epidemiological typing of Bacillus cereus by amplified fragment length polymorphism. Letters in Applied Microbiology, 30(5): 358-363.
Rodriguez-Palacios, A., Stämpfli, H.R., Duffield, T., Peregrine, A. S., Trotz-Williams, A., Arroyo, L.G., Brazier, J.S., Weese, J.S. 2006. Clostridium difficile PCR ribotypes in calves, Canada. Emerging Infectious Diseases, 12(11): 1730-1736.

Schmittgen, T.D., Livak, K.J. 2008. Analyzing real-time PCR data by the comparative CT method. Nature Protocols, 3(6): 1101-1108.

Selvey, S., Thompson, E.W., Matthaei, K., Lea, R.A., Irving, M.G., Griffiths, L.R. 2001. $\beta$-Actin-an unsuitable internal control for RT-PCR. Molecular and Cellular Probes, 15: 307-311.

Seo, K.H., Brackett, R.E. 2005. Rapid, specific detection of Enterobacter sakazakii in infant formula using a real-time PCR assay. Journal of Food Protection, 68(1): 59-63.

Shannon, K., Lee, D.Y., Trevors, J., Beaudette, L. 2007. Application of real-time quantitative PCR for the detection of selected bacterial pathogens during municipal wastewater treatment. Science of The Total Environment, 382(1): 121-129.

Sharma, V.K., Carlson, S.A. 2000. Simultaneous Detection of Salmonella Strains and Escherichia coli O157:H7 with Fluorogenic PCR and SingleEnrichment-Broth Culture. Applied and Environmental Microbiology, 5472-5476.

Shi, H., Xu, W., Trinha, Q., Luoa, Y., Liang, Z., Li, Y., Huanga, K. 2012. Establishment of a viable cell detection system for microorganisms in wine based on ethidium monoazide and quantitative PCR. Food Control, 27(1): 81-86.

Shipley, G.L. 2007. An introduction to real-time PCR. (Real-time PCR, Taylor and Francis Group Publishers, New York: Ed. Dorak, M.T.) 1-37.

Singh, J., Batish, V.K., Grover, S., 2009. A scorpion probe-based real-time PCR assay for detection of $E$. coli $\mathrm{O} 157: \mathrm{H} 7$ in dairy products. Foodborne Pathog. Dis., 6: 395-400.

Sun, F., Wu, D., Qiu, Z., Jin, M., Wang, X., Li, J. 2010. Development of real-time PCR systems based on SYBR Green for the specific detection and quantification of Klebsiella pneumoniae in infant formula. Food Control, 21: 487-491.

Takahashi, H., Kimura, B., Tanaka, Y., Shinozaki, J., Suda, T., Fujii, T. 2009. Real-time PCR and enrichment culture for sensitive detection and enumeration of Escherichia coli. J. Microbiol Methods, 79(1):124-127.

Toplak, N., Kovac, M., Piskernik, S., Mozina, S.S., Jersek B. 2011. Detection and quantification of Campylobacter jejuni and Campylobacter coli using real-time multiplex PCR. Journal of Applied Microbiology, 112: 752-764.

Trakhna, F., Harf-Monteil, C., AbdelNour, A., Maaroufi, A., Gadonna-Widehem, P. 2008. Rapid Aeromonas hydrophila identification by TaqMan PCR assay: comparison with a phenotypic method. Letters in Applied Microbiology, 49: 186-190. 
Trakhna, F., Maaroufi, A., Gadonna-Widehem, P. 2013. Using a real-time quantitative polymerase chain reaction (PCR) method for reliable enumeration of Aeromonas hydrophila in water samples. African Journal of Microbiology Research, 7(19): 2119 2126.

Tyagi, S., Kramer, F. R. 2012. Molecular Beacons in Diagnostics. F1000 Medicine Reports, 4(10): 1-6.

Ueda, S., Yamaguchi, M., Iwase, M., Kuwabara, Y. 2013. Detection of Emetic Bacillus cereus by RealTime PCR in Foods. Biocontrol Science, 18(4): $227-$ 232.

Valasek, M.A., Repa, J.J. 2005. The power of real-time PCR. Adv Physiol Educ., 29(3): 151-9.

Velusamy, V., Arshak, K., Korostynka, O., Vaseashta, A., Adley, C. 2012. Real Time Detection of Foodborne Pathogens - For Food Quality Monitoring \& Biosecurity . (Technological Innovations in Sensing and Detection of Chemical, Biological, Radiological, Nuclear Threats and Ecological Terrorism, Springer Publishers, USA: Ed. Vaseashta, A.T., Braman, E., Susmann, P.) 149158.

Velusamy, V., Arshak, K., Korostynska, O., Oliwa, K., Adley, C. 2010. An overview of foodborne pathogen detection: in the perspective of biosensors. Biotechnology Advances, 28(2): 232-254.

Wang, W., Chen, K., Xu, C. 2006. DNA quantification using EvaGreen and a real-time PCR instrument. Anal Biochem., 356(2): 303-305.
Wang, X., Zhu, C. Q., Xu, X., Zhou, G. 2012. Realtime PCR with internal amplification control for the detection of Cronobacter spp. (Enterobacter sakazakii) in food samples. Food Control, 25(1): 144-149.

Whitcombe, D., Theaker, J., Guy, S.P., Brown, T., Little, S. 1999. Detection of PCR products using self-probing amplicons and fluorescence. Nat Biotechnol., 17: 804-7.

Wiedmann, M., Czajka, J., Barany, F., Batt, C. A. 1992. Discrimination of Listeriamonocytogenes from other Listeria species by ligase chain reaction. Applied and Environmental Microbiology, 58(11): 3443 3447.

Wilhelm, J., Pingoud, A. 2003. Real-Time Polymerase Chain Reaction. Chem BioChem., 4: 1120-1128.

Wolffs, P.F.G., Glencross, K., Norling, B., Griffiths, M.W., 2007. Simultaneous quantification of pathogenic Campylobacter and Salmonella in chicken rinse fluid by a flotation and real-time multiplex PCR procedure. Int. J. Food Microbiol., 117: 50-54.

Wong, M.L., Medrano, J.F. 2005. Real-time PCR for mRNA quantitation. Biotechniques, 39(1): 75-85.

Yaron, S., Matthews, K.R. 2002. A reverse transcriptase-polymerase chain reaction assay for detection of viable Escherichia coli O157: H7: investigation of specific target genes. Journal of Applied Microbiology, 92(4): 633-640. 